\title{
Morphometric Assessment of Spleen Dimensions and Its Correlates Among Individual Living in Arba Minch Town, Southern Ethiopia
}

Solomon Demissie ( $\sim$ sol12162129@gmail.com )

Arba Minch University

\section{Prasad Mergu}

Arba Minch University

Teshale Fikadu

Arba Minch University

Tadios Hailu

Arba Minch University

Getachew Abebe

Arba Minch University

\section{Mengistu Warsa}

Arba Minch General Hospital

\section{Research Article}

Keywords: Morphometry, Spleen dimensions, Arba Minch

Posted Date: January 28th, 2021

DOI: https://doi.org/10.21203/rs.3.rs-143967/v1

License: (c) (i) This work is licensed under a Creative Commons Attribution 4.0 International License. Read Full License 


\section{Abstract}

Introduction: The spleen is a vital lymphoid soft organ that demands constant attention from the clinical point of view. It is multi-dimensional organs that enlarge in all dimensions in disease conditions. The detection of the spleen by palpation on physical examination is not an approval of an enlarged spleen because an unenlarged spleen may palpable. Therefore, this study aimed to assess the Morphometry of spleen dimensions and its correlates among individuals living in Arba Minch Town by sonographic examinations.

Methods and Materials: Community-based cross-sectional study was conducted in Arba Minch town from February 1 to March 30, 2020. A multi-stage systematic and simple random sampling technique was applied to select study participants. Data was entered into Epi-Data version 3.1software and exported to SPSS version 20 software for analysis.

Result: A total of 708 individuals, 390 (55.1\%) males and 318 (44.9\%) females were included in the current study. The mean splenic length, width, thickness and volume were $10.24 \mathrm{~cm}, 4.79 \mathrm{~cm}, 3.93 \mathrm{~cm}$, and $109.34 \mathrm{~cm}^{3}$, respectively. The mean spleen length, width, thickness and volumes among males were $10.64 \mathrm{~cm}, 4.92 \mathrm{~cm}, 4.05 \mathrm{~cm}$ and $119.81 \mathrm{~cm}^{3}$ and among females were $9.75 \mathrm{~cm}, 4.63 \mathrm{~cm}, 3.78 \mathrm{~cm}$ and $96.50 \mathrm{~cm}^{3}$ respectively. Significant negative correlations were found between age and spleen dimensions. Significant positive correlations were observed between spleen dimensions and height, weight, Body Mass Index, and Body Surface area. But, the correlation between width and body mass index was non-significant ( $p$-value $>0.05)$.

Conclusion and Recommendations: The spleen dimensions were higher in males than females and have a significant positive correlation with height, weight, Body Mass Index and Body Surface Area except for the width. Further studies in different parts of the country have to be done to have normative data on the dimension of Spleen in Ethiopia.

\section{Introduction}

The spleen is the largest lymphoid soft organ that lies in the left hypochondrium between the fundus of the stomach and the diaphragm where it is entirely covered by the inferior thoracic rib cage (1). It extends from the 9th - 11th ribs on the left side with its long axis runs parallel to the 10th rib (2). Its shape is ovoid with a convex outer diaphragmatic surface and an indented inner visceral surface related to the stomach, left kidney, pancreatic tail, left suprarenal gland and left colic flexure $(3,4)$. The apex lies in line with the spine of the 10 th thoracic vertebra about $4 \mathrm{~cm}$ from the midline and the base does not descend beyond the midaxillary line (5).

The spleen is an encapsulated intraperitoneal organ entirely covered with peritoneum except for its hilum where the splenic branches of the splenic artery and vein enter and leave $(5,6)$. It is supported by a phrenico-colic ligament that originates from the colon from the bottom and anchored to the stomach by gastro-splenic ligament and to the left kidney by a lien renal ligament (7).

In diseases condition spleen enlarges at different rates in its dimensions and most easily vulnerable organs (8-10). A variety of diseases condition alters spleen dimensions, where splenomegaly and its consequence becomes a primary clinical concern in any part of the world $(11,12)$. Splenomegaly is commonly seen in about $63 \%$ of patients with $\mathrm{PAH}$ (13), IM $(14,15)$, malaria $(16,17)$, lymphoma (18), kala-azar (19), typhoid fever $(20)$, and others. The altered splenic dimensions and structure during these diseases result in asymptomatic enlargement and complications such as hematoma formation, rupture, hypersplenism, ectopic spleen, and torsion that affect other adjacent organs $(21,22)$. The splenic atrophy is also another common problem seen in diseases like sickle cell anemia (23) and celiac disease 
(24). The progressive atrophy as a result of repeated attacks of vaso-occlusion and infarction caused by these diseases leads to auto splenectomy $(23,25,26)$.

The average dimensions of the spleen are $12.5 \mathrm{~cm}, 7.5 \mathrm{~cm}$ and $2.5 \mathrm{~cm}$ in length, width and thickness respectively and 150-200 grams in weight, but its dimensions vary considerably $(2,27)$. The literature revealed that spleen dimensions are affected by geographical differences, races, nutritional status and anthropometric measurements (28-30). Due to these variations, a normal range of spleen dimensions varies from country to country where some accept less than 12 $\mathrm{cm}$ spleen length (31) and others accept less than $13 \mathrm{~cm}$ spleen length in their clinical practice (32), etc. The study conducted in Northern Ethiopia revealed also these variations where normal spleen length ranges vary from 7- $13.6 \mathrm{~cm}$ (33).

In clinical practice, palpation is commonly used to detect spleen dimensions. However, detection of the spleen by palpation is not reliable because the normal spleen is palpable and a non-palpable spleen is not normal sized at all (34-37). Similarly, diagnoses of diseases associated with the spleen by physical examination and laboratory findings do not determine parasite load, the extent of diseases and complications caused in case of severe cases (38).

Although, Literatures indicates radiological imaging modalities like ultrasound can detect the extent, complications, and classify the severity of cases, yet enough attention is not given in clinical practice (39). On sonographic examinations, the spleen is crescent-shaped with the outer margin is smooth and convex and the inner margin is irregularly indented. Its echotexture is homogeneous and more echogenic than healthy liver tissue and markedly hyperechoic compared to kidney tissue (13).

Even though there are several studies in which the spleen dimensions have been analyzed in many countries, there is still a lack of adequate information in African populations including Ethiopia. Therefore, the study is aimed to assess the morphometry of spleen dimensions and to determine its variations with sex, age, height, weight, BMI, and BSA among individuals living in Arba Minch town.

\section{Methodology And Material}

The community-based cross-sectional study was conducted from February 1 to March 30, 2020, in Arba Minch town, SNNP region which is located at an altitude of $1285 \mathrm{~m}$ above sea level and about $437 \mathrm{~km}$ far from Addis Ababa.708 individuals (390 males and 318 females) fulfilling inclusion criteria were included in the current study of spleen dimensions. The data collection checklist was developed after reviewing different literature $(33,40,41)$. The checklist was developed in English and the face validity was assessed by a public health specialist and Anatomist. The checklist was composed of socio-demographic factors (age and sex); anthropometric measurements (height, weight, BSA and BMI) and spleen dimensions (length, width, thickness and volume). A multi-stage sampling technique was used to select study participants. Individuals selected at household levels were sent to the nearest health center or selected private clinics for sonographic examination. History and physical examination of individuals were taken before sonographic examination by clinicians. Then the individuals were sent for sonographic examinations which were performed by two radiology technologists using portable and stationary ultrasound machines equipped with 3.5 $\mathrm{MHz}$ curvilinear probes. The subjects were examined in the supine or right oblique positions for overall abdominal examinations to exclude cases associated with the spleen. Then spleen dimensions measurements were performed for apparently healthy individuals. The spleen was scanned during suspended respiration. The splenic length was measured in a longitudinal plane between the dome of the spleen and the splenic tip. The splenic width was also measured in a longitudinal plane perpendicular to the length between the medial and lateral borders of the spleen. The splenic thickness was measured on the transverse plane from the posterior margin to the anterior margin. The volume 
was calculated using the ellipsoid formula during the analysis $(41,52)$. The spleen dimensions were measured three times and recorded on the checklist then the average value was taken during analysis (42-45).

Finally, the baseline data including age and sex were recorded for all participants. The height and weight were measured with the stadiometer and weighing machine for all participants respectively. BSA and BMI were calculated during the analysis.

\section{Inclusion and Exclusion Criteria}

\section{Inclusion criteria}

All apparently healthy individuals and age greater than 13 years $(46,47)$

\section{Exclusion criteria}

- Individuals with a recurrent clinical history of malaria

- Recurrent history of typhoid fever

- Individuals with a history of infections (infectious mononucleosis, kala-azar, endocarditis, sarcoidosis, toxoplasmosis).

- Recent history of upper abdominal surgery

- Individuals with any case finding on sonographic examinations (cirrhosis, melanoma, lymphoma, metastasis, any cystic or solid massive lesions)

- Individuals with Diabetic Mellitus (DM) cases.

- Hypertensive individuals

- Individuals with a history of heart disease

- Individuals with a recent abdominal traumatic condition (within the previous 6 months)

- Pregnant women

\section{Study variables}

\section{Dependent variables}

Spleen dimensions (length, width, thickness and volume)

\section{Independent variables}

- Age

- Sex

- Height

- Weight

- BSA and

- BMI

\section{Operational definitions}

Apparently healthy individuals: - defined as the absence of disease based on clinical signs and symptoms of individuals normally assessed by history, physical evaluation and sonographic examinations $(48,49)$. 


\section{Data Analysis and Processing}

Data was entered into Epi-Data version 3.1software and exported to SPSS version 20 software for analysis. A descriptive summary was used to present the result. Independent- Samples t-test was conducted to compare the mean spleen dimensions among sex and one-way ANOVA was conducted to compare the mean spleen dimensions among age groups. $T$ and $F$ statistics were calculated and $P<0.05$ was taken as statistically significant. To determine the relationships between the studied parameters, Pearson correlation coefficients were calculated

\section{Result}

\section{Socio-demography}

A total of 708 (55.1\% male and $44.9 \%$ female) participants were included in the study with a $100 \%$ response rate. The mean age of the study participant was $32.28 \pm 13.17$ years with a majority of $278(39.3 \%)$ were between the age group of 21 - 30 years (Table 1$)$.

Table 1: Age and sex distribution of the study participants living in Arba Minch town, 2020

\begin{tabular}{|llll|}
\hline \multirow{2}{*}{ Age category in years } & Sex & \multicolumn{2}{c|}{ Total } \\
\cline { 2 - 3 } & Male & Female \\
\hline $11-20$ & 72 & 58 & 130 \\
\hline $21-30$ & 154 & 124 & 278 \\
\hline $31-40$ & 88 & 66 & 154 \\
\hline $41-50$ & 28 & 38 & 66 \\
\hline Above 50 & 48 & 32 & 80 \\
\hline Total & 390 & 318 & 708 \\
\hline$\%$ & $55.1 \%$ & $44.9 \%$ & $100.0 \%$ \\
\hline
\end{tabular}

\section{Anthropometric measurements}

The mean height, weight, BMI, and BSA of the study participants were $167.56 \pm 6.69 \mathrm{~cm}, 61.75 \pm 8.23 \mathrm{~kg}, 21.98 \pm 2.53$, and $1.67 \pm 0.13$ respectively (Table 2 ).

Table 2: Anthropometric measurement of the study participants living in Arba Minch town, 2020

\begin{tabular}{|llllll|}
\hline & N & Minimum & Maximum & Mean & Std. Deviation \\
\hline Height $(\mathrm{cm})$ & 708 & 150.00 & 188.00 & 167.5607 & 6.68908 \\
\hline Weight $(\mathrm{kg})$ & 708 & 44.00 & 89.00 & 61.7446 & 8.22522 \\
\hline BMI & 708 & 14.81 & 30.67 & 21.9785 & 2.53226 \\
\hline BSA & 708 & 1.38 & 2.10 & 1.6924 & .13246 \\
\hline Total & 708 & & & & \\
\hline
\end{tabular}




\section{Overall spleen dimensions}

The mean splenic length, width, thickness, and volume were $10.24 \pm 1.458 \mathrm{~cm}, 4.79 \pm 0.99 \mathrm{~cm}, 3.93 \pm 1.05 \mathrm{~cm}$, and $109.34 \pm 61.68 \mathrm{~cm}^{3}$, respectively. The dimensions lie with the range of (7.07-13.91) cm in length, $(2.32-7.20) \mathrm{cm} \mathrm{in}$ width, (2.10-7.09) $\mathrm{cm}$ in thickness, and (20.83-349.03) $\mathrm{cm}^{3}$ in volume (Table 3).

Table 3: Average spleen dimensions of study participants living in Arba Minch town, 2020

\begin{tabular}{|c|c|c|c|c|c|c|c|}
\hline & \multirow[t]{2}{*}{ Minimum } & \multirow[t]{2}{*}{ Maximum } & & & \multirow{2}{*}{$\begin{array}{l}\text { Std. } \\
\text { Deviation } \\
\text { Statistic }\end{array}$} & \multicolumn{2}{|c|}{ 95\% Confidence Interval } \\
\hline & & & Mean & $\begin{array}{l}\text { Std. } \\
\text { Error }\end{array}$ & & Lower bound. & Upper bound. \\
\hline Length & 7.07 & 13.91 & 10.2421 & .05441 & 1.44771 & 10.14 & 10.35 \\
\hline Width & 2.32 & 7.20 & 4.7889 & .03751 & .99811 & 4.72 & 4.86 \\
\hline Thickness & 2.10 & 7.09 & 3.9311 & .03960 & 1.05367 & 3.85 & 4.00 \\
\hline Volume & 20.83 & 349.03 & 109.3381 & 2.31811 & 61.68084 & 104.79 & 113.89 \\
\hline
\end{tabular}

\section{Comparison of spleen dimensions by sex}

The mean spleen length, width, thickness and volume among males were $10.64 \pm 1.38 \mathrm{~cm}, 4.92 \pm 1.03 \mathrm{~cm}$, and 4.05 $\pm 1.09 \mathrm{~cm}$ and among females were $119.81 \pm 65.32 \mathrm{~cm}^{3}$ and $9.75 \pm 1.38 \mathrm{~cm}, 4.63 \pm 0.93 \mathrm{~cm}, 3.78 \pm 0.98 \mathrm{~cm}$ and 96.50 $\pm 54.31 \mathrm{~cm}^{3}$ respectively. A significant difference in splenic dimensions was observed in which the dimensions were higher among males than females (Table 4).

Table 4: Independent sample t-test analysis in comparison of spleen dimensions by sex among individuals living in Arba Minch town, 2020

\begin{tabular}{|c|c|c|c|c|c|c|c|c|}
\hline & \multirow[t]{2}{*}{ Sex } & \multirow[t]{2}{*}{$\mathrm{N}$} & \multirow[t]{2}{*}{ Mean } & \multirow[t]{2}{*}{ Std. Deviation } & \multicolumn{2}{|c|}{$95 \%$ Cl for Mean } & \multirow[t]{2}{*}{ T-test } & \multirow[t]{2}{*}{ P-value } \\
\hline & & & & & Lower Bound & Upper Bound & & \\
\hline \multirow[t]{2}{*}{ Length } & Male & 390 & 10.6433 & 1.37963 & 10.5098 & 10.78569 & \multirow[t]{2}{*}{8.575} & \multirow[t]{2}{*}{0.000} \\
\hline & Female & 318 & 9.7500 & 1.37759 & 9.6067 & 9.9044 & & \\
\hline \multirow[t]{2}{*}{ Width } & Male & 390 & 4.9155 & 1.03225 & 4.8118 & 5.0181 & \multirow[t]{2}{*}{3.812} & \multirow[t]{2}{*}{0.000} \\
\hline & Female & 318 & 4.6336 & .93295 & 4.5366 & 4.7385 & & \\
\hline \multirow[t]{2}{*}{ Thickness } & Male & 390 & 4.0537 & 1.09359 & 3.9444 & 4.1768 & \multirow[t]{2}{*}{3.49} & \multirow[t]{2}{*}{0.001} \\
\hline & Female & 318 & 3.7809 & .98357 & 3.6774 & 3.8898 & & \\
\hline \multirow[t]{2}{*}{ Volume } & Male & 390 & 119.8054 & 65.31931 & 113.4938 & 126.7284 & \multirow[t]{2}{*}{5.183} & \multirow[t]{2}{*}{0.000} \\
\hline & Female & 318 & 96.5009 & 54.30818 & 90.9121 & 102.8142 & & \\
\hline
\end{tabular}


Significant variations were observed in all spleen dimensions among age categories of study participants. The lowest value was recorded in age groups of above 50 years $(9.36 \mathrm{~cm}, 4.35 \mathrm{~cm}, 3.56 \mathrm{~cm}$ and $86.33 \mathrm{~cm} \otimes$ for length, width, thickness, and volume respectively) and the highest in age groups of $31-40$ years $(10.76 \mathrm{~cm}, 4.91 \mathrm{~cm}, 4.2$ and 126.02 $\mathrm{cm} \otimes$ for length, width, thickness, and volume respectively). As the age increases all spleen dimensions were found to decrease above the age of 40 years (Table 5).

Table 5: One-way ANOVA analysis of different age groups in comparison of spleen dimensions among the study participants living in Arba Minch town, 2020

\begin{tabular}{|c|c|c|c|c|c|c|c|c|}
\hline & \multirow[t]{2}{*}{ Age (in a year) } & \multirow[t]{2}{*}{$\mathrm{N}$} & \multirow[t]{2}{*}{ Mean } & \multirow[t]{2}{*}{ SD } & \multicolumn{2}{|l|}{$95 \% \mathrm{Cl}$} & \multirow[t]{2}{*}{$\mathrm{F}$} & \multirow[t]{2}{*}{ P-value } \\
\hline & & & & & Lower B. & Upper B. & & \\
\hline \multirow[t]{6}{*}{ Length } & $11-20$ & 130 & 10.14 & 1.21 & 9.93 & 10.35 & \multirow[t]{6}{*}{16.53} & \multirow[t]{6}{*}{0.000} \\
\hline & $21-30$ & 278 & 10.37 & 1.31 & 10.23 & 10.53 & & \\
\hline & $31-40$ & 154 & 10.76 & 1.49 & 10.52 & 10.99 & & \\
\hline & $41-50$ & 66 & 9.72 & 1.57 & 9.34 & 10.11 & & \\
\hline & $>50$ & 80 & 9.36 & 1.56 & 9.02 & 9.71 & & \\
\hline & Total & 708 & 10.24 & 1.45 & 10.14 & 10.35 & & \\
\hline \multirow[t]{6}{*}{ Width } & $11-20$ & 130 & 4.90 & 0.90 & 4.75 & 5.06 & \multirow[t]{6}{*}{6.43} & \multirow[t]{6}{*}{0.000} \\
\hline & $21-30$ & 278 & 4.85 & 0.92 & 4.75 & 4.96 & & \\
\hline & $31-40$ & 154 & 4.91 & 1.08 & 4.74 & 5.08 & & \\
\hline & $41-50$ & 66 & 4.54 & 1.04 & 4.28 & 4.80 & & \\
\hline & $>50$ & 80 & 4.35 & 1.08 & 4.11 & 4.59 & & \\
\hline & Total & 708 & 4.79 & 0.99 & 4.72 & 4.86 & & \\
\hline \multirow[t]{6}{*}{ Thickness } & $11-20$ & 130 & 3.99 & 0.87 & 3.85 & 4.15 & \multirow[t]{6}{*}{5.94} & \multirow[t]{6}{*}{0.000} \\
\hline & $21-30$ & 278 & 3.91 & 0.99 & 3.79 & 4.02 & & \\
\hline & $31-40$ & 154 & 4.20 & 1.21 & 4.01 & 4.39 & & \\
\hline & $41-50$ & 66 & 3.73 & 1.08 & 3.47 & 3.99 & & \\
\hline & $>50$ & 80 & 3.56 & 1.05 & 3.32 & 3.79 & & \\
\hline & Total & 708 & 3.93 & 1.05 & 3.85 & 4.01 & & \\
\hline \multirow[t]{6}{*}{ Volume } & $11-20$ & 130 & 109.59 & 51.77 & 100.61 & 118.58 & \multirow[t]{6}{*}{6.55} & \multirow[t]{6}{*}{0.000} \\
\hline & $21-30$ & 278 & 109.70 & 54.92 & 103.22 & 116.19 & & \\
\hline & $31-40$ & 154 & 126.02 & 71.26 & 114.68 & 137.37 & & \\
\hline & $41-50$ & 66 & 96.26 & 69.01 & 79.29 & 113.22 & & \\
\hline & $>50$ & 80 & 86.33 & 64.20 & 72.04 & 100.61 & & \\
\hline & Total & 708 & 109.34 & 61.68 & 104.79 & 113.89 & & \\
\hline
\end{tabular}




\section{Correlation analysis of spleen dimensions}

Pearson's correlation analysis showed that a significant correlation was observed among all evaluated spleen dimensions and height, weight, BSA, and BMI except the width which showed non-significant correlations with BMI $(p>0.05)$. The highest positive correlation was observed between spleen length and height of participants $(r=0.518)$ while the lowest was between spleen thickness and BMI of participants $(r=0.111)$. Spleen length, width, thickness and volume were negatively correlate with age $(r=-0.183,-0.165,-0.107$ and -0.100 respectively) (Table 6$)$.

Table 6: Pearson's correlation analysis of spleen dimensions with age, height, weight, BMI and BSA among individuals living in Arba Minch town, 2020 


\begin{tabular}{|c|c|c|c|c|c|c|c|c|c|c|}
\hline & & Height & Weight & BMI & BSA & Length & Width & Thickness & Volume & Age \\
\hline \multirow[t]{2}{*}{ Height } & $\mathrm{R}$ & 1 & $.516^{\star \star}$ & $-.112^{\star \star}$ & $.693^{* *}$ & $.518^{* *}$ & $.411^{* *}$ & $.354^{\star \star}$ & $.437^{\star *}$ & .002 \\
\hline & $\begin{array}{l}\text { Sig. (2 } \\
\text { tailed) }\end{array}$ & & .000 & .003 & . 000 & .000 & .000 & .000 & .000 & .960 \\
\hline \multirow[t]{2}{*}{ Weight } & $\mathrm{R}$ & $.516^{* *}$ & 1 & $.790^{* *}$ & $.975^{\star *}$ & $.442^{* *}$ & $.307^{\star \star}$ & $.312^{\star \star}$ & $.374^{* *}$ & $.309^{* *}$ \\
\hline & $\begin{array}{l}\text { Sig. } \\
(2- \\
\text { tailed) }\end{array}$ & .000 & & .000 & 0.000 & .000 & .000 & .000 & .000 & .000 \\
\hline \multirow[t]{2}{*}{ BMI } & $\mathrm{R}$ & $-.112^{\star \star}$ & $.790^{\star *}$ & 1 & $.636^{* *}$ & $.143^{* *}$ & .066 & $.111^{* *}$ & $.120^{* *}$ & $.363^{\star *}$ \\
\hline & $\begin{array}{l}\text { Sig.(2- } \\
\text { tailed) }\end{array}$ & .003 & .000 & & .000 & .000 & .080 & .003 & .001 & .000 \\
\hline \multirow[t]{2}{*}{ BSA } & $\mathrm{R}$ & $.693^{* *}$ & $.975^{\star \star}$ & $.636^{* *}$ & 1 & $.506^{* *}$ & $.364^{\star \star}$ & $.354^{\star \star}$ & $.427^{* *}$ & $.262^{* *}$ \\
\hline & $\begin{array}{l}\text { Sig. } \\
(2- \\
\text { tailed) }\end{array}$ & .000 & 0.000 & .000 & & .000 & .000 & .000 & .000 & .000 \\
\hline \multirow[t]{2}{*}{ Length } & $\mathrm{R}$ & $.518^{\star \star}$ & $.442^{\star \star}$ & $.143^{* *}$ & $.506^{* *}$ & 1 & $.707^{* *}$ & $.621^{\star \star}$ & $.803^{* *}$ & $-.183^{* *}$ \\
\hline & $\begin{array}{l}\text { Sig. } \\
(2- \\
\text { tailed) }\end{array}$ & .000 & .000 & .000 & .000 & & .000 & .000 & .000 & .000 \\
\hline \multirow[t]{2}{*}{ Width } & $\mathrm{R}$ & $.411^{\star \star}$ & $.307^{\star \star}$ & .066 & $.364^{\star \star}$ & $.707^{* *}$ & 1 & $.690^{\star \star}$ & $.864^{* *}$ & $-.165^{* *}$ \\
\hline & $\begin{array}{l}\text { Sig. } \\
(2- \\
\text { tailed) }\end{array}$ & .000 & .000 & .080 & .000 & .000 & & .000 & .000 & .000 \\
\hline \multirow[t]{2}{*}{ Thickness } & $\mathrm{R}$ & $.354^{* *}$ & $.312^{\star \star}$ & $.111^{* *}$ & $.354^{\star \star}$ & $.621^{* *}$ & $.690^{* *}$ & 1 & $.900^{* *}$ & $-107^{\star *}$ \\
\hline & $\begin{array}{l}\text { Sig. } \\
(2- \\
\text { tailed) }\end{array}$ & .000 & .000 & .003 & .000 & .000 & .000 & & .000 & .004 \\
\hline \multirow[t]{2}{*}{ Volume } & $\mathrm{R}$ & $.437^{\star \star}$ & $.374^{\star \star}$ & $.120^{* *}$ & $.427^{* k}$ & $.803^{* *}$ & $.864^{* *}$ & $.900^{* \star}$ & 1 & $-.100^{* *}$ \\
\hline & $\begin{array}{l}\text { Sig. } \\
(2- \\
\text { tailed) }\end{array}$ & .000 & .000 & .001 & .000 & .000 & .000 & .000 & & .008 \\
\hline \multirow[t]{2}{*}{ Age } & $\mathrm{R}$ & .002 & $.309^{\star \star}$ & $.363^{* \star}$ & $.262^{\star \star}$ & $-.183^{\star \star}$ & $-.165^{\star *}$ & $-.107^{\star \star}$ & $-.100^{\star \star}$ & 1 \\
\hline & $\begin{array}{l}\text { Sig. } \\
(2- \\
\text { tailed) }\end{array}$ & .960 & .000 & .000 & .000 & .000 & .000 & .004 & .008 & \\
\hline
\end{tabular}

\section{Discussion}

This study describes the morphometry of spleen dimensions; compare the presence of a significant difference between sex and age as well as dimensional correlations with anthropometric measurements. The mean of spleen dimensions was also compared with other studies and consistency and the difference was noted in the current study. 
The sonography assessment of spleen dimensions provides essential inputs for clinicians in daily clinical practice for proper diagnosis of splenomegaly $(32,44,53-55)$. The result of this study gives reference values which helps radiologist for appropriate diagnosis of diseases associated to splenomegaly and splenic atrophy, for the surgeons to appropriately design surgical cases associated to spleen, for hematologist and immunologist for proper diagnosis of various gastrointestinal and hematological diseases and forensic studies (56-59).

The mean of spleen length at $95 \% \mathrm{Cl}$ with SD was $10.24 \pm 1.45 \mathrm{~cm}$ which is consistent with studies conducted in Russia and Kashmir $(60,61)$. But, less than from study conducted in Turkey(42), Bangladesh, Jordan and North India $(8,41,62,63)$ and greater than from study conducted in Nepal, Nigeria, Sudan and Northern Ethiopia $(29,33,42,64)$.

The mean of spleen width was $4.79 \pm 0.998 \mathrm{~cm}$ which is less than from study conducted in Bangladesh, Nepal, Kashmir, North India and Nigeria $(8,42,44,61,63,64)$ and greater than from study conducted in Sudan and Northern Ethiopia $(29,33)$.

The mean of spleen thickness in the current study was $3.93 \pm 1.054 \mathrm{~cm}$ which is consistent with the study conducted in Ethiopia (33). But less than from studies conducted in Russia, Bangladesh, Jordan, Nepal, north India, and Nigeria $(8,41,42,44,60,63,64)$ and is greater than from a study conducted in Sudan (29).

The mean spleen volume was $109.34 \pm 61.68 \mathrm{~cm}^{3}$ which is less than from studies conducted in Saud Arabia, Russia, Jordan and Nepal $(41,53,60,64,65)$ but greater than from the study conducted in Sudan and Ethiopia $(33,40)$.

The overall dimensional difference of the current study from studies conducted in other areas may be due to age group difference, sample size difference, anthropometric measurements, geographical differences, nutritional status, physical exercise, and race difference which were stated in different literature $(32,44,59,66-69)$.

The fact that fewer average total red cell mass among females and due to genetic factor splenic dimensions was lower in females $(31,70)$. This is supported by our findings where all dimensions were significantly larger in males than females. This is consistent with the study conducted in Turkey, Saudi, Nigeria and Sudan $(40,53,59,71,72)$. But, a non-significant difference in spleen volume was observed in a study conducted in Nepal (64) which is due to the small sample size and age range difference where 1-90 years were included in the study of Nepal. Also, the length was higher among females than males in the study conducted in Egypt (73) which is maybe due to nutritional status where Egyptian culture accepts excess weight gain among women than men due to fertility considerations $(74,75)$.

The spleen dimensions decrease in older age due to a decrease in the number and size of B cell follicles of the white pulp of the spleen which decreases with a decrease of germinal center in older age groups (76-78). This is supported by our finding where the lengths, width, thickness, and volumes were significantly increased up to the age of 40 years then decrease in older ages. This is consistent with the study conducted in Iraq, western Nepal, and India (32, 45, 54, $55,79,80)$. But, this different from the study conducted in Pakistan, Jordan, and Nigeria $(41,42,68,72)$. The difference is maybe due to nutritional status where larger anthropometric measurements and obesity were observed in the study of Pakistan (68), Jordan (41) and Nigeria (42, 72).

From a physiological perspective as individuals' body parameters (height, weight, BMI, and BSA) increase, the blood volume increase and requiring larger spleens for filtration (41). This is supported by our finding where all dimensions were positively correlated with height, weight, BMI, and BSA $(p<0.05)$. This is consistent with the study conducted in Jordan, USA, India, Sudan $(29,31,37,41,61,63,79)$. But, different from the study conducted in Turkey, Nigeria and Egypt $(42,62,68,73)$. This may be due to nutritional status where the study participants in the study of Turkey, Nigeria and Egypt were overweight than ours. The non-significant correlations observed between spleen width and BMI in the current study $(P=0.080)$ is consistent with the study conducted in Sudan (40).

Page 10/16 


\section{Limitation Of The Study}

- The current study does not include the history of the physical exercise of the participants. A laboratory finding of study participants is not known.

\section{Conclusion}

The mean value of spleen dimensions of the Arba Minch town community was $10.24 \mathrm{~cm}, 4.79 \mathrm{~cm}, 3.93 \mathrm{~cm}$, and $109.34 \mathrm{~cm}^{3}$, in length, width, thickness, and volume respectively. The study indicated that there is a significant morphometric difference in splenic dimensions between males and females. Only the width shows a non-significant correlation with BMI and significant negative correlations was seen between age and spleen dimensions. This study gives baseline information for clinicians as well as for academicians about the morphometric variation of spleen dimensions which helps in diagnosing pathological cases associated with spleen both splenomegaly as well as splenic atrophy.

\section{Abbreviations And Acronym}

AP: - Antero-Posterior

BMI: -Body Mass Index

BSA: -Body-Surface Area

Cl: - Confidence Interval

CSA: - Central statistical agency

CT Scans: - Computed Tomography Scans

IM: - Infectious Mononucleosis

MHz: -Megahertz.

MRI: - Magnetic resonance imaging

P: - P-value

PAH: - Pulmonary arterial hypertension

R: - Pearson correlation coefficient

RT: - Radiologic Technologists

SD: - Standard Deviation

SNNP: Southern Nations, Nationalities and peoples

SPSS: - Statistical Package for the Social Sciences.

US: - Ultrasonography 


\section{Declarations}

The ethical approval letter was obtained from Arba Minch University's ethical review board. The letter of cooperation was obtained from the town administration and written informed consent was obtained from the study participants. For participants less than 18 years parental written consent was obtained after informing the purpose of the study. All methods were carried out following relevant guidelines and regulations.

\section{Consent for publication}

Not applicable

\section{Competing interests}

The authors declare that they have no competing of interest.

\section{Funding}

No specific funding for the study

\section{Availability of data and materials}

All relevant data are included in the article. The dataset of this study are available from the corresponding authors upon reasonable request.

\section{Authors' contributions}

SD conceptualize and designed the study, conducted the analysis, interpret and write the first draft of the paper for publication. GA and MW were involved in the data analysis and interpret the data, and reviewed the manuscript for publication. TF, PM and TH supervise the data collection process. All authors read and approve the final manuscript before submission.

\section{Acknowledgments}

The authors would like to acknowledge the Arba Minch University for allowing the study to be conducted and the data collectors for their willingness to collect the data. We would like also to thank Arba Minch town health office, Arba Minch town health centers and private clinics for their full cooperation to take our study in their institutions, facilitating study setting and for the unreserved offer of their medical equipment required for the data collection. Lastly, we would like to thank our study participants for their full cooperation to participate in our study.

\section{References}

1. Singh V. Textbook of anatomy abdomen and lower limb: Elsevier Health Sciences; 2014: 93p.

2. Sinnatamby CS. Last's Anatomy E-Book: Regional and Applied: Elsevier Health Sciences; 2011.

3. Nayak BS, Somayaji S, Soumya K. A Study on the Variations of Size, Shape and External Features of the Spleen in South Indian Population. International Journal of Morphology. 2011;29(3): 675-677.

4. Chaudhry SR, Panuganti K. Anatomy, Abdomen and Pelvis. Spleen StatPearls Treasure Island (FL): StatPearls Publishing StatPearls Publishing LLC. 2019: 455 - 71. 
5. Moore KL, Dalley A, Agur A. Clinically oriented anatomy II. Philadelphia: Wolters Kluwer Health/Lippincott Williams \& Wilkins. 2014: $263-165$.

6. Faiz O, Blackburn S, Moffat D. Anatomy at a Glance: John Wiley \& Sons; 2011.

7. Frank HN. Netter Atlas of Human Anatomy 7th Ed 2018. Elsevier; 2018: 58p.

8. Paul FN, Taher MA, Roy SK, Sarkar S, Sultana S. Splenic volume: Correlation between ultrasonogram and standard CT measurements. Bangladesh Medical Research Council Bulletin. 2017; 43(2):58-62.

9. Vancauwenberghe T, Snoeckx A, Vanbeckevoort D, Dymarkowski S, Vanhoenacker FM. Imaging of the spleen: what the clinician needs to know. Singapore medical journal. 2015;56(3):133.

10. Fomin D, Chmieliauskas S, Petrauskas V, Sumkovskaja A, Ginciene K, Laima S, et al. Traumatic spleen rupture diagnosed during postmortem dissection: A STROBE-compliant retrospective study. Medicine. 2019;98(40): P e17363.

11. Leoni S, Buonfrate D, Angheben A, Gobbi F, Bisoffı Z. The hyper-reactive malarial splenomegaly: a systematic review of the literature. Malaria journal. 2015;14(1):185.

12. Lv Y, Lau WY, Li Y, Deng J, Han X, Gong $X$, et al. Hypersplenism: history and current status. Experimental and therapeutic medicine. 2016;12(4):2377-82.

13. Tonelli AR, Yadav R, Gupta A, Arrossi AV, Heresi GA, Dweik RA. Spleen size in idiopathic and heritable pulmonary arterial hypertension. Respiration. 2013;85(5):391-9.

14. Jenson HB. Epstein-Barr virus. Pediatrics in Review-Elk Grove. 2011;32(9):375.

15. Johannsen EC, KM K. Epstein-Barr virus (infectious mononucleosis, Epstein-Barr virus-associated malignant diseases, and other diseases). Principles and Practice of Infectious Diseases. 2015;7.

16. Mahgoub H, Gasim GI, Musa IR, Adam I. Severe Plasmodium vivax malaria among Sudanese children at New Halfa Hospital, eastern Sudan. Parasites \& vectors. 2012;5(1):154.

17. Alkadarou T, Musa A, Alkadarou A, Mahfouz MS, Troye-Blomberg M, Elhassan AM, et al. Immunological characteristics of hyperreactive malarial splenomegaly syndrome in Sudanese patients. Journal of tropical medicine. 2013;2013.

18. Smeltzer J, Habermann TM, Timucin T, Nagorney D, Ristow K, Colgan JP, et al. Long Term Clinical Outcomes in Patients with Massive Splenomegaly and Non-Hodgkin's Lymphoma Treated with Splenectomy. American Society of Hematology. 2012; 120 (21): 2692.

19. Varma N, Naseem S. Hematologic changes in visceral leishmaniasis/kala-azar. Indian Journal of Hematology and Blood Transfusion. 2010;26(3):78-82.

20. Sahu N, Rath S, Padhy RN. Role of Abdominal Ultrasound in the Diagnosis of Typhoid Fever in Pediatric Patients. Journal of Medical Ultrasound. 2016;24(4):150-3.

21. Aubrey-Bassler FK, Sowers N. 613 cases of splenic rupture without risk factors or previously diagnosed disease: a systematic review. BMC emergency medicine. 2012;12(1):11.

22. Elizalde-Torrent A, Val F, Azevedo ICC, Monteiro WM, Ferreira LC, Fernández-Becerra C, et al. Sudden spleen rupture in a Plasmodium vivax-infected patient undergoing malaria treatment. Malaria journal. 2018;17(1):79.

23. Babadoko A, Ibinaye P, Hassan A, Yusuf R, ljei I, Aiyekomogbon J, et al. Autosplenectomy of sickle cell disease in Zaria, Nigeria: An ultrasonographic assessment. Oman Medical Journal. 2012;27(2):121.

24. Brousse V, Buffet P, Rees D. The spleen and sickle cell disease: the sick (led) spleen. British journal of hematology. 2014;166(2):165-76.

25. Di Sabatino A, Brunetti L, Maffè GC, Giuffrida P, Corazza GR. Is it worth investigating splenic function in patients with celiac disease? World Journal of Gastroenterology: WJG. 2013;19(15):2313.

Page 13/16 
26. Al-Salem AH. Splenic complications of sickle cell anemia and the role of splenectomy. ISRN hematology. 2010;2011.

27. Steiniger BS, Wilhelmi V, Berthold M, Guthe M, Lobachev O. Locating human splenic capillary sheaths in virtual reality. Scientific reports. 2018;8(1):1-10.

28. Patel N. Morphological Variation of The Spleen-A Case Report. 2018; 8(2):958-964.

29. Yousef M. Local Reference of splenic volume in Healthy Sudanese Subjects Sonographically. Journal of Biomedical Engineering and Medical Imaging. 2018;5(4):30.

30. Abdollah F, Novara G, Briganti A, Scattoni V, Raber M, Roscigno M, et al. Trans-rectal versus trans-perineal saturation rebiopsy of the prostate: is there a difference in cancer detection rate? Urology. 2011;77(4):921-5.

31. Chow KU, Luxembourg B, Seifried E, Bonig H. Spleen size is significantly influenced by body height and sex: the establishment of normal values for spleen size at the US with a cohort of 1200 healthy individuals. Radiology. 2016;279(1):306-13.

32. Chakraborti S, Saha N, Debbarma B, Das S, Leishram D. Normal spleen length by ultrasonography in adults of Tripura. J Dent Med Sci. 2016;1:55-60.

33. Tekle Y, Gudadhe DR, Abreha M, Muche A, Tegegne Z, Hiware SD. Morphometric Assessment of the Normal Dimensions of the Adult Spleen in North-west Ethiopia Region-A Radiological Study. Annals of International Medical and Dental Research. 2018; 4(4):34-7.

34. Singh A, Ansari H, Das J, Chandra N. Ultrasonographic Measurement of Splenic length in relation with Height in Bihari Adult population a prospective study. Journal of Anatomical Society of India. 2011;60(2):188-9.

35. Kumar L, Bansal A. Splenomegaly-a clinical approach. API textbook of medicine 9th ed New Delhi: Jaypee Brothers Medical Publishers. 2012:926-7.

36. Singhal RK, Patel D, Patel S, Shrivastava AK. Ultrasonographic Measurement of Splenic Length in Relation with Height in Gujarati Population. Indian Journal of Anatomy. 2016;5(3):219.

37. Singh A, Chandra N, Ansari H, Das J. Measurement of the spleen width in relation with the height in the adults of Bihar-an ultrasonographic study. Journal of Anatomical Sciences. 2016;24:13-7.

38. Mouatcho JC, Goldring JD. Malaria rapid diagnostic tests: challenges and prospects. Journal of medical microbiology. 2013;62(10):1491-505.

39. Benter T, Klühs L, Teichgräber U. Sonography of the spleen. Journal of Ultrasound in Medicine. 2011;30(9):128193.

40. Yousif JM. Measurement of Normal Spleen in Sudanese by Using Ultrasonography: Sudan University of Science and Technology; 2016: 61.

41. Badran DH, Kalbouneh HM, Al-Hadidi MT, Shatarat AT, Tarawneh ES, Hadidy AM, et al. Ultrasonographic assessment of splenic volume and its correlation with body parameters in a Jordanian population. Saudi medical journal. 2015;36(8):967.

42. Mustapha Z, Tahir A, Tukur M, Bukar M, Lee W-K. Sonographic determination of normal spleen size in an adult African population. European journal of radiology. 2010;75(1):e133-e5.

43. Eze CU, Agwu K, Ezeasor D, Ochie K, Aronu A, Agwuna K, et al. Sonographic biometry of spleen among school-age children in Nsukka, Southeast, Nigeria. African health sciences. 2013;13(2):384-92.

44. Caglar V, Alkoc O, Uygur R, Serdaroglu O, Ozen O. Determination of normal splenic volume in relation to age, gender and body habitus: a stereological study on computed tomography. Folia morphologica. 2014;73(3):331-8.

45. Mittal R, Chowdhary D. A pilot study of the normal measurements of the liver and spleen by ultrasonography in the Rajasthani population. Journal of Clinical and Diagnostic Research. 2010;4(4):2733-6.

Page 14/16 
46. Özdikici M. The relationship between splenic length in healthy children from the Eastern Anatolia Region and sex, age, body height and weight. Journal of ultrasonography. 2018;18(72):5.

47. Warnakulasuriya DTD, Peries PPUC, Rathnasekara YAC, Jayawardena KTM, Upasena A, Wickremasinghe AR. Ultrasonographic parameters of the liver, spleen and kidneys among a cohort of school children in Sri Lanka. BMC pediatrics. 2017;17(1):192.

48. Organization WH. Vitamin and mineral requirements in human nutrition: World Health Organization; $2004: 3$.

49. Ustinova OI. Apparently Healthy Human Being: the Necessity to Refine the Notion. Life Science Journal. 2014;11(10):524-6.

50. Feber J, Krásničanová H. Measures of body surface area in children. Handbook of Anthropometry: Springer; 2012. p. $1249-56$.

51. Nuttall FQ. Body mass index: obesity, BMI, and health: a critical review. Nutrition today. 2015;50(3):117.

52. Kodikara S, Nanayakkara B, Nanayakkara B, llayperuma I. Splenic Morphometry in a Group of Sri Lankan Adult Population-A Preliminary Cadaveric Study. 2017: 44-52.

53. Siddiqui MA, Ali AHA, Bedewi MA, Serhan 00. Estimation of standard splenic volume in Saudi Arabian adult population: using 3D reconstruction of Abdominal CT scan Images. Open Journal of Internal Medicine. 2014;4(01):7.

54. Arora N, Sharma P, Sahai A, Singh R. Sonographic measurements of the spleen in relation to age; A prospective study in North Indian Adults. Journal of Anatomical Society of India. 2010;59(2):177-81.

55. Sharma K, Lamichhane P, Sharma B, Sharma B. Sonographic Measurement of Spleen in Relation to Age: A Prospective Study among Adult Nepalese People in Western Nepal. Journal of Gandaki Medical College-Nepal. 2017;10(1):11-6.

56. Mubbunu L, Bowa K, Petrenko V, Silitongo M. Correlation of internal organ weights with body weight and body height in normal adult Zambians: a case study of Ndola Teaching Hospital. Anatomy research international. 2018;2018(4687538):1-5.

57. Okuma H, Gonoi W, Ishida M, Shirota G, Kanno S, Shintani Y, et al. Comparison of volume and attenuation of the spleen between postmortem and antemortem computed tomography. International journal of legal medicine. 2016;130(4):1081-7.

58. Palmiere C, Tettamanti C, Scarpelli MP, Tse R. The forensic spleen: Morphological, radiological, and toxicological investigations. Forensic science international. 2018;291:94-9.

59. Çeliktas M, Özandaç S, Göker P, Bozkir MG. Sonographic determination of normal spleen size in Turkish adults. Int J Morphol. 2015;33(4):1401-5.

60. Izranov V, Palvanova U, Gordova V, Perepelitsa S, Morozov S. Ultrasound Criteria of Splenomegaly. Radiologist. 2019;1(1):1001.

61. Gul S, Itoo MS, Jahangir M, Kamal Y. Sonologic Assessment of Dimensions of Spleen in Normal Adult Kashmiri Population and their Correlation with Weight and Height. 2018: 5(2): 63-9.

62. Serter S, Ceylan C, Tunçyürek Ö, Örgüç Ş, Pabuçcu Y. Sonographic evaluation of spleen size and prevalence of accessory spleen in a healthy male Turkish population. 2010; 27(1): 25-8.

63. Asghar A, Naaz S, Agrawal D, Sharma P. Morphometric study of the spleen in North Indian adult population: CT Scan image-based study. J Clin Diagn Res. 2011;5(5):974-7.

64. Chhetri P, Poudel S. Normal splenic volume assessment on CT in the Nepalese population. Abdom Radiol. (2018) 43:2455-2461

Page 15/16 
65. Alhazmi DA, Mazi OA, Alsulami AM, Abduljabbar AH, Wazzam M. Normal size and values in adult population in the western region of saudi arabia. 2017; 4(2): 166-9.

66. Sonmez G, Ozturk E, Basekim CC, Mutlu H, Kilic S, Onem Y, et al. Effects of altitude on spleen volume: sonographic assessment. Journal of Clinical Ultrasound. 2007;35(4):182-5.

67. Purdy GM, James MA, Rees JL, Ondrus P, Keess JL, Day TA, et al. Spleen reactivity during incremental ascent to altitude. Journal of Applied Physiology. 2019;126(1):152-9.

68. Khan SA, Yasmeen S, Adil H, Adil SO, Huda F, Khan S. Sonographic evaluation of normal liver, spleen, and renal parameters in the adult population: A multicenter study. Journal of the College of Physicians and Surgeons Pakistan. 2018;28(11):834.

69. Shephard RJ. Responses of the human spleen to exercise. Journal of sports sciences. 2016;34(10):929-36.

70. Murphy WG. The sex difference in hemoglobin levels in adults-mechanisms, causes, and consequences. Blood reviews. 2014;28(2):41-7.

71. Udoaka A, Enyi C, Agi C. Sonological evaluation of the liver, spleen and the kidneys in an adult southern Nigerian population. Asian Journal of Medical Sciences. 2013;5(2):33-6.

72. Ehimwenma O, Tagbo MT. Determination of the normal dimension of the spleen by ultrasound in an endemic tropical environment. Nigerian medical journal: journal of the Nigeria Medical Association. 2011;52 (3):198.

73. Ahmed OF. Assessment of normal hepatosplenic spans using ultrasound in the Egyptian population. Nat Sci 2017; 15 (8):215-219.

74. Galal OM. The nutrition transition in Egypt: obesity, under nutrition and the food consumption context. Public health nutrition. 2002; 5(1a):141-8.

75. Kanter R, Caballero B. Global gender disparities in obesity: a review. Advances in nutrition. 2012;3(4):491-8.

76. Himamoni D, Das T, Talukdar K. Age-Related Histological changes of Human Spleen. 2016: 56-61.

77. Turner VM, Mabbott NA. Influence of aging on the microarchitecture of the spleen and lymph nodes. Biogerontology. 2017;18(5):723-38.

78. Alex L, Rajan ML, Xavier B, Jacob P, Rani KD, Lakshmi GV. Microscopic study of the human spleen in different age groups. Int J Res Med Sci. 2015;3(7):1701-6.

79. Arora N, Sharma P, Sahai A, Singh R. Sonographic measurement of the spleen: splenic length in adults and its correlation with different parameters. Journal of the Anatomical Society of India. 2013;62(1):57-61.

80. Estephan MF, Al-Saadi WI, Funjan MM. Possible anthropometric explanation of age-related changes in splenic volume in a sample of healthy Iraqi individuals using ultrasonography. Iraqi Journal of Medical Sciences.

2012;10(4):312-20. 